\title{
Necroptosis in the Pathophysiology of Disease
}

\author{
Mitri K. Khoury, Kartik Gupta, Sarah R. Franco, and Bo Liu
}

From the Division of Vascular Surgery, Department of Surgery, University of Wisconsin-Madison, Madison, Wisconsin

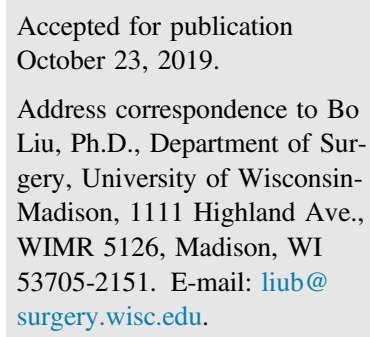

\begin{abstract}
Over the past 15 years, elegant studies have demonstrated that in certain conditions, programed cell death resembles necrosis and depends on a unique molecular pathway with no overlap with apoptosis. This form of regulated necrosis is represented by necroptosis, in which the receptor-interacting protein kinase- 3 and its substrate mixed-lineage kinase domain-like protein play a crucial role. With the development of knockout mouse models and molecular inhibitors unique to necroptotic proteins, this cell death has been found to occur in virtually all tissues and diseases evaluated. There are different immunologic consequences depending on whether cells die through apoptosis or necroptosis. Therefore, distinguishing between these two forms of cell death may be crucial during pathologic evaluations. In this review, we provide an understanding of necroptotic cell-death and highlight diseases in which necroptosis has been found to play a role. We also discuss the inhibitors of necroptosis and the ways these inhibitors have been used in preclinical models of diseases. These two discussions offer an understanding of the role of necroptosis in diseases and will foster efforts to pharmacologically target this unique yet pervasive form of programed cell death in the clinic. (Am J Pathol 2020, 190: 272-285; https://doi.org/10.1016/j.ajpath.2019.10.012)
\end{abstract}

The concept of cell death has dramatically changed over the past 2 decades. Previously, it was believed that apoptosis and necrosis are two different forms of cell death, the former being regulated and the latter incidental. Current and emerging data have disproven this binary view, and experimental evidence now supports that molecular regulation is not unique to apoptosis, but rather, some forms of necrosis also involve regulatory mechanisms that consist of membrane receptors and intracellular signaling transduction molecules. The beststudied form of regulated or programed necrosis is called necroptosis. Necroptosis has emerged as a crucial pathologic process involved in many diseases (Figure 1). The expanding list of novel proteins in regulated necrosis has also fostered the development of new small-molecule inhibitors, some of which are currently in clinical trials. This review focuses on preclinical models of disease and therapeutic interventions involving necroptosis. The pathophysiologic relevance of regulated necrosis and highlight the promising translational potential of necroptosis inhibitors are also discussed.

\section{Necroptosis}

Apoptosis and necroptosis differ in several aspects. Morphologically, cells undergoing apoptosis maintain the integrity of their cell membranes. In contrast, cells undergoing necroptosis show disruption of their cell membranes, which is a key characteristic of necrosis. Therefore, cells undergoing necroptosis are indistinguishable from those undergoing necrosis, using standard histologic techniques. Although apoptosis and necroptosis frequently have common triggers, ${ }^{3}$ the intracellular signaling pathways leading to the execution of apoptosis and necroptosis differ. In the same way that caspases are key intracellular mediators of apoptosis, receptor-interacting protein kinases (RIPKs) are essential mediators in necroptosis. In addition to sharing some common cell death triggers, apoptosis and necroptosis intersect at multiple points during the signal transduction

Supported by NIH grants R01HL088447 (B.L. and S.F.), R01HL122562 (B.L.), and T32HL110853 (M.K.); and American Heart Association grant 17PRE33670082 (K.G.).

Disclosures: None declared. 


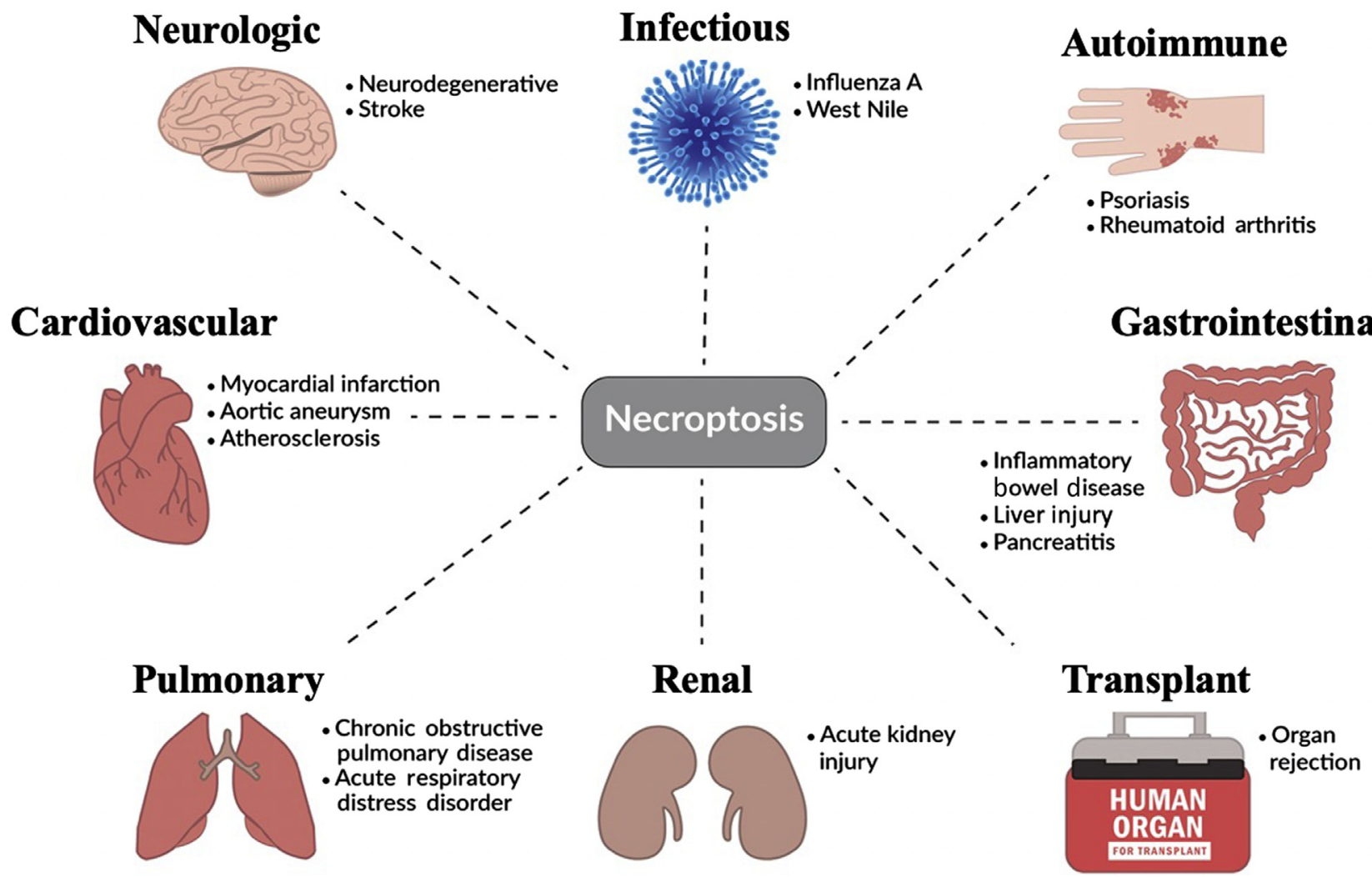

Figure 1 Necroptosis plays a role in the pathogenesis of various diseases across the body, including conditions of the neurologic, cardiovascular, pulmonary, and gastrointestinal systems. Necroptosis also plays a role in infectious and autoimmune diseases. Recently, necroptosis was reported to mediate organ rejection in both cardiac and renal allografts. ${ }^{1,2}$

process. For example, the ability of caspase- 8 to antagonize necroptosis by cleaving necroptosis mediators is one of the best-understood examples of how apoptosis and necroptosis intersect. ${ }^{4,5}$

In several ways, necroptosis is a cellular response to environmental stress that can be caused by chemical and mechanical injury, inflammation, or infection. The current understanding of necroptosis has largely developed around the TNF- $\alpha$ receptor system (Figure 2). TNF- $\alpha$ is a pleiotropic molecule capable of inciting a survival, apoptotic, or necroptotic response based on the assembly of sequential but mutually exclusive cell death complexes. ${ }^{6,7}$ Depending on the cellular context, engagement of TNF- $\alpha$ can trigger the formation of complex I (a prosurvival complex that signals through NF- $\mathrm{KB}$ ). However, in situations in which RIPK1 is de-ubiquitinated, the complex becomes an apoptotic complex IIa. Furthermore, the absence of caspase- 8 , in addition to elevated levels of RIPK3, alters the complex to IIb (also called the necrosome). This necrosome contains RIPK1, RIPK3, and Fas-associated protein with death domain that allow the cell to undergo necroptosis via direct phosphorylation of mixed-lineage kinase domain-like protein (MLKL) by RIPK3 ${ }^{8,9}$ Phosphorylation of MLKL results in a poreforming oligomer that punctures the plasma membrane and causes subsequent cell death. ${ }^{10}$ Other effectors downstream of RIPK3 include mitochondrial serine/ threonine-protein phosphatase ${ }^{11}$ and $\mathrm{Ca}^{2+} / \mathrm{calm}-$ odulin-dependent protein kinase (CaMK)-II, ${ }^{12}$ and the list is likely to be expanded.

\section{Necroptosis and Inflammation}

Cell death and inflammation have been found to be closely related. Many proinflammatory cytokines (such as TNF- $\alpha$ and IL-1 $)$ as well as inflammatory cells are capable of causing cell death. ${ }^{13}$ There are different effects on inflammation depending on whether cells die from apoptosis or necroptosis. Generally, apoptosis generates a lesser inflammatory response by maintaining the integrity of the plasma membrane and avoiding the exposure of intracellular contents. ${ }^{14}$ In contrast, necroptosis may directly activate and modulate inflammatory responses by releasing intracellular contents through the ruptured plasma membrane. The relationship between necroptosis and inflammation has been seen in other pathologic states and is thought to be the central component of the pathogenesis of necroptosis-associated diseases. In addition, necroptosis regulators RIPK1 and RIPK3 have been shown to play an independent role in inflammation irrespective of cell death. ${ }^{15,16}$ 
A
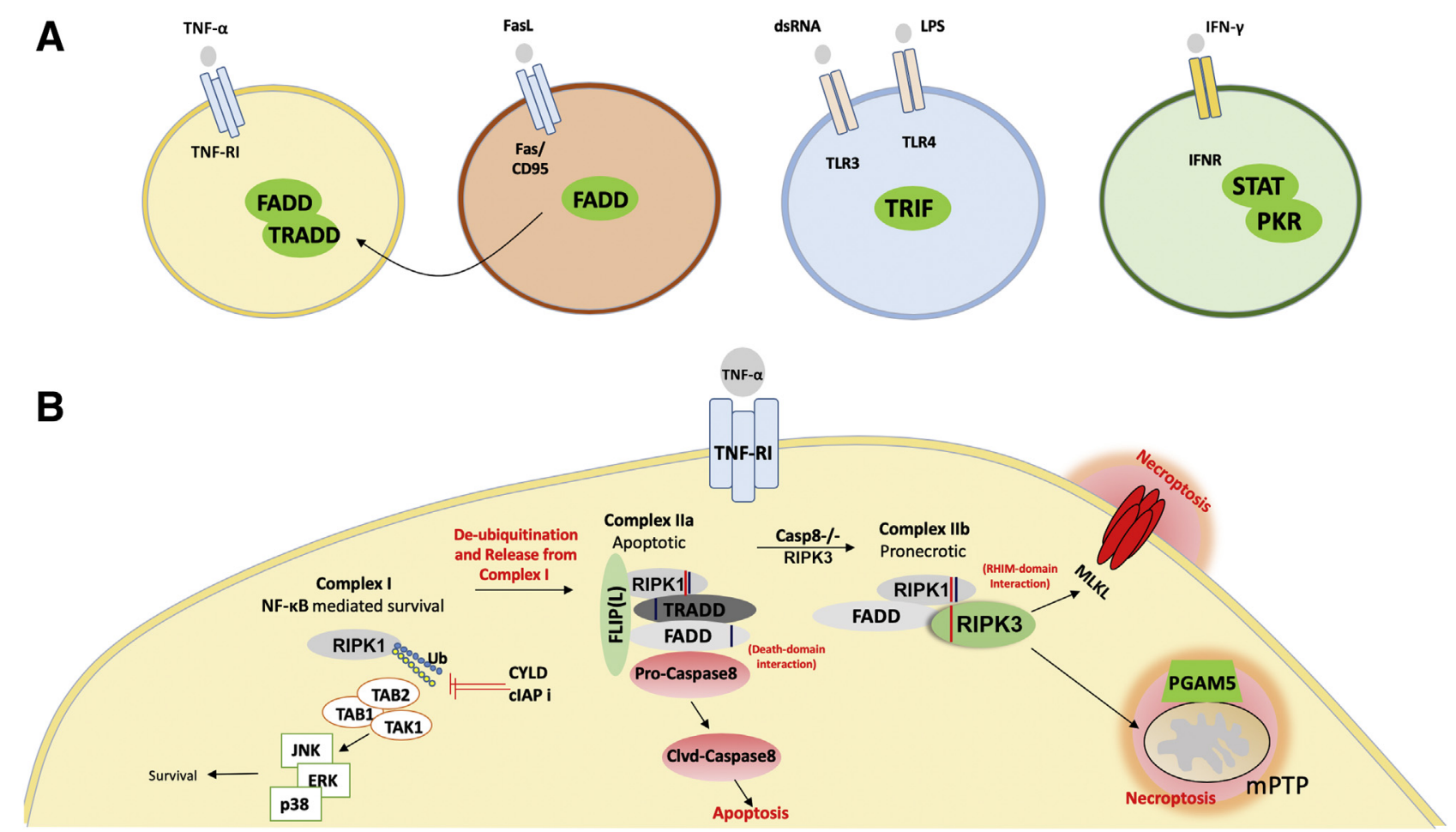

Figure 2 Signal transduction events downstream of tumor necrosis factor receptor 1 (TNF-RI) that cause necroptosis. A: 0verall schematic highlighting the unique receptors and intracellular signal-transduction components that activate necroptosis on binding to their ligands. The receptors include TNF-receptor superfamily (TNF-RI and Fas/CD95), Toll-like-receptor superfamily (TLR3/4), and interferon receptor (IFNR). The signal transducers are in green circles. Note: all signaling components converge on RIP3 for the execution of necroptosis and an example of the downstream events is shown in B. B: Signal transduction events downstream of TNF-RI that cause necroptosis. Activation of the TNF-RI, by engagement of TNF- $\alpha$, can trigger the formation of a prosurvival complex (Complex I), which contains receptor-interacting protein kinase-1 (RIPK1). When Complex I is ubiquitinated, this leads to NF- $\kappa B$ mediated survival. Alternately, de-ubiquitination of RIPK1 by either ubiquitin carboxyl-terminal hydolase (CYLD) or pharmacologic targeting of cellular inhibitors of apoptosis (cIAPs) can activate complex IIa. Complex IIa is protein ensemble consisting of tumor necrosis factor receptor type 1 associated death domain protein (TRADD), Fasassociated protein with death domain (FADD), and RIP1. In the presence of caspase 8, complex II preferentially drives toward IIa leading to apoptosis. However, in the absence of caspase 8 and presence of RIP3, complex II switches to IIb, which is pronecroptotic. Complex IIb then leads to necroptosis via the phosphorylation of mixed-lineage kinase domain-like pseudokinase (MLKL) by RIPK3 or its association of phosphoglycerate mutase family member (PGAM)-5 with RIPK3 that causes opening of the mitochondrial permeability transition pore complexes (mPTPs). CaMKII, $\mathrm{Ca}^{2+} / \mathrm{calmodulin}$-dependent protein kinase II; FLIP, FLICE-like inhibitory protein; JNK, c-Jun N-terminal kinase; LPS, lipopolysaccharide; PKR, protein kinase R; RHIM, RIPK homotypic interaction motif; TLR, Toll-like receptor; TRIF, TIR-domain-containing adapter-inducing interferon- $\beta$.

\section{Necroptosis Inhibitors}

The discovery of necroptosis led to the development of a variety of inhibitors targeting the regulatory components of this death process, namely RIPK1, RIPK3, and MLKL. Necrostatins are tryptophan-based compounds that inhibit the kinase activity of RIPK $1 .{ }^{17}$ Necrostatin (Nec)-1 was first discovered during a chemical screening for necroptosis antagonists. ${ }^{17}$ It was subsequently demonstrated that Nec-1 binds to and stabilizes RIPK1 in an inactive conformation and therefore protects cells against necroptosis. ${ }^{18} \mathrm{Nec}-1 \mathrm{~s}$, a derivative of NEC-1, has shown improved stability and higher binding specificity to RIPK1 compared with Nec- $1 .{ }^{19}$ Both Nec-1 and Nec-1s have been used in numerous disease models (Diseases Involving Necroptosis) and have shown strong clinical potential. However, Nec-1 or Nec-1s has moderate potency and poor pharmacokinetic properties. ${ }^{19-21}$ GSK2982772 is another RIPK1 inhibitor recently developed by Harris et $\mathrm{al}^{22}$ that more effectively inhibits RIPK1 while blocking many TNF-dependent inflammatory responses. GSK2982772 is currently being tested in clinical trials for psoriasis, rheumatoid arthritis, and ulcerative colitis. ${ }^{23}$

Although RIPK3 is thought to be a more specific regulator of necroptosis than is RIPK1, the translation of RIPK3 inhibitors to clinical applications has been lagging. Kaiser et $\mathrm{al}^{24}$ discovered several compounds such as GSK'840, GSK'843, and GSK' 872 that can bind to and inhibit RIPK3 with high potency. However, when administered alone, these compounds induce apoptosis in a concentration-dependent manner. ${ }^{7} \mathrm{Li}$ et $\mathrm{al}^{25}$ reported that dabrafenib, a B-raf inhibitor used for treating melanoma, also displays inhibitory effects on RIPK3. Dabrafenib inhibits the kinase activity of RIPK 3 by competing to the ATP binding site and has been shown to alleviate acetaminophen-induced necrosis in human hepatocytes. That study provides a promising approach to repurposing drugs that are currently on the market as necroptosis inhibitors.

A class of hybrid inhibitors of both RIPK1 and RIPK3 has been identified. These include the US Food and 
Drug Administration-approved chemotherapeutic drugs ponatinib and pazopanib. ${ }^{26}$ However, these tyrosine kinase inhibitors are unlikely to have broad applications because of their significant cardiotoxicity. Our laboratory recently developed a novel dual inhibitor, GSK'074. In multiple cell lines, GSK'074 inhibited necroptosis and inflammation without causing apoptosis. More importantly, GSK'074 attenuated abdominal aortic aneurysm formation in mouse models. ${ }^{27}$

MLKL is the downstream mediator of necroptosis and might be a more specific target for abrogating necroptosis. However, compared with RIPK1 and RIPK3, fewer inhibitors targeting MLKL have been discovered. Currently, the most widely used MLKL inhibitor is necrosulfonamide. However, because necrosulfonamide is able to bind only to the human variant of MLKL, ${ }^{9}$ it has been challenging to evaluate necrosulfonamide in preclinical disease models.

Although there have been significant advancements in identifying inhibitors of necroptosis, the complexity surrounding the necroptotic pathway has made it difficult to capitalize on the proteins known to regulate these pathways. The overlap of inducing apoptosis while inhibiting necroptosis using existing inhibitors, in addition to the lack of specificity of some of these inhibitors, represent some of the obstacles to making necroptosis inhibitors viable therapeutic modalities.

\section{Mouse Models of Necroptosis}

Mice with deletions in genes of the necroptosis pathway are tools crucial for understanding necroptotic signaling, as well for identifying the biological processes and diseases in which necroptosis plays an indispensable role. Knockouts of major necroptosis members such as RIPK3 and MLKL are available. Unfortunately, Ripkl ${ }^{-1-}$ mice demonstrate perinatal lethality. However, various versions of Ripkl and Ripk3 knock-in mice have been generated and their use has led to unexpected findings. For instance, Ripk3D161N mice die from spontaneous apoptosis, but other kinase-dead mice are viable, which further demonstrates the complex biology associated with RIPK3 ${ }^{28}$ Additionally, the two kinase-dead Ripk1 knock-in mice-Ripk1K45A (bearing a point mutation in exon 3 in the catalytic lysine of Ripkl) and Ripk1D138N/D138N (conserved aspartate at position 138 is mutated to asparagine)-are viable and fertile. These transgenic studies suggest that the kinase activities of RIPK1 are necessary for a necroptotic response but not essential for embryonic development. ${ }^{29}$ Many of the genetic mouse lines have been combined with the models of diseases to study the roles of RIP3, RIPK3, and MLKL in pathophysiology (Table $1^{1,2,30-63}$ ).

\section{Diseases Involving Necroptosis}

The discovery of necroptosis has revolutionized the way that the scientific community views cell death. Necroptosis has been found to be involved in numerous pathologic states. Although the development of disease-specific necroptosis inhibitors is lacking, the results from investigations using commercially available necroptosis inhibitors on various disease models have been promising. Our knowledge and efforts regarding necroptosis and disease have dramatically expanded over the years, especially given the ability to model diseases in mice in which major necroptosis mediators can be genetically deleted or modified. Here, we review various pathologies associated with necroptosis throughout the body.

\section{Stroke}

Ischemic stroke is due to compromised blood flow to the brain, usually resulting from thrombus/emboli within the cerebrovascular system. The ischemic core is a region of the brain that has undergone irreversible damage, whereas the penumbra is a region of cerebral tissue that has sustained the ischemic insult but can still be revived. Currently, there is no pharmacologic treatment tailored to preventing or hindering the progression of the penumbra to infarcted tissue.

A landmark paper by Degterev et $\mathrm{al}^{30}$ demonstrated that stimulation of the Fas/TNFR receptor family triggered necroptosis in mice. The investigators also found that necroptosis contributed to delayed mouse ischemic brain injury in vivo after middle cerebral artery occlusion. In addition, the administration of Nec-1 significantly reduced the infarct volume. However, Newton et $\mathrm{al}^{31}$ found that deletion of the Ripk3 gene did not affect hypoxia-induced cerebral edema or infarct volume after middle cerebral artery occlusion. Given these contradicting results, it is possible that the benefits seen via inhibition of RIPK1 may be unrelated to necroptosis.

The mediators of necroptosis also have a functional role in stroke-related inflammation. Inflammation is one of the pathologic changes that occur after a stroke. Microglia are the macrophage-like cells in the central nervous system. Microglia and macrophages are activated and recruited to the site of injury through a variety of chemical signals and switch their phenotypes between two polarized conditions. ${ }^{64}$ The M1 type expresses proinflammatory factors and acts to remove necrotic tissue. The M2 type is anti-inflammatory and expresses growth factors to aid with repair and restoration of damaged brain tissue. ${ }^{65}$ Manipulation of this microglial/macrophage polarization is a neuroprotective strategy after stroke. ${ }^{66}$ In a recent publication, Yang et $\mathrm{al}^{67}$ demonstrated a link between necroptosis and the M1/M2 polarization of the ischemic cortex of the brain. The authors discovered that without RIPK3 or MLKL, both microglia and macrophages polarized to the M2 phenotype in the ischemic cortex. Ex vivo, treatment with oxygen-glucosedeprived media (a model that is used to mimic ischemia) in RIPK3-containing neurons led to the secretion of proinflammatory cytokines such as IL-18 and TNF- $\alpha$. In contrast, RIPK3-deficient neurons treated with oxygen-glucose- 
Table 1 Summary of in Vivo Experiments in Various Disease Models

\begin{tabular}{|c|c|c|c|c|c|}
\hline System/disorder & Animal model (species) & Strain & Inhibitors & Effect seen & $\overline{\text { References }}$ \\
\hline \multicolumn{6}{|l|}{ Neurologic } \\
\hline \multirow[t]{2}{*}{ Stroke } & $\begin{array}{l}\text { Middle cerebral artery } \\
\text { occlusion (mouse) }\end{array}$ & $\mathrm{C} 57 \mathrm{BL} / 6$ & $\mathrm{Nec}-1 \mathrm{~s}$ & Reduced infarct volume & 30 \\
\hline & $\begin{array}{l}\text { Middle cerebral artery } \\
\text { occlusion (mouse) }\end{array}$ & Ripk3 $3^{-1-}$ & None & No effect & 31 \\
\hline $\begin{array}{l}\text { Alzheimer } \\
\text { disease }\end{array}$ & $\begin{array}{l}\text { Amyloid precursor } \\
\text { protein/presenilin } 1 \\
\text { (mouse) }\end{array}$ & $\operatorname{Tg} 2576$ & $\mathrm{Nec}-1 \mathrm{~s}$ & $\begin{array}{l}\text { Reduction in } A \beta \text { plaques and } \\
\text { behavioral deficits }\end{array}$ & 32 \\
\hline \multicolumn{6}{|l|}{ Cardiovascular } \\
\hline \multirow[t]{3}{*}{$\begin{array}{l}\text { Myocardial } \\
\text { infarction }\end{array}$} & $\begin{array}{l}\text { Left anterior descending } \\
\text { coronary artery ligation } \\
\text { (mouse) }\end{array}$ & $\operatorname{Ripk}^{-1-}$ & None & $\begin{array}{l}\text { Improved ejection fraction, } \\
\text { decreased inflammation }\end{array}$ & 33 \\
\hline & $\begin{array}{l}\text { Ischemia/reperfusion } \\
\text { injury (mouse) }\end{array}$ & Ripk3-/- & None & $\begin{array}{l}\text { Reduced infarct size, improved } \\
\text { ejection fraction }\end{array}$ & 12 \\
\hline & $\begin{array}{l}\text { Left anterior descending } \\
\text { coronary artery ligation } \\
\text { (mouse) }\end{array}$ & $\mathrm{C} 57 \mathrm{BL} / 6$ & $\mathrm{Nec}-1$ & $\begin{array}{l}\text { Reduced inflammation, reduced } \\
\text { infarct size }\end{array}$ & 34,35 \\
\hline \multirow{3}{*}{$\begin{array}{l}\text { Aortic } \\
\text { aneurysm }\end{array}$} & Elastase model (mouse) & Ripk3-/- & None & AAA formation prevented & 36 \\
\hline & Elastase model (mouse) & $\mathrm{C} 57 \mathrm{BL} / 6$ & Nec-1, Nec-1s & Decreased aneurysm diameter & 37 \\
\hline & $\begin{array}{l}\text { Calcium phosphate } \\
\text { (mouse) }\end{array}$ & $\mathrm{C} 57 \mathrm{BL} / 6$ & GSK'074 & Decreased aneurysm diameter & 27 \\
\hline \multicolumn{6}{|l|}{ Pulmonary } \\
\hline \multirow{3}{*}{$\begin{array}{l}\text { Respiratory } \\
\text { distress } \\
\text { syndrome }\end{array}$} & $\begin{array}{l}\text { IV injection oleic acid } \\
\text { (rat) }\end{array}$ & Sprague-Dawley & None & $\begin{array}{l}\text { Elevated levels of RIPK1, RIPK3, } \\
\text { and MLKL in lung tissue }\end{array}$ & 38 \\
\hline & $\begin{array}{l}\text { Intratracheal injection LPS } \\
\quad \text { (mouse) }\end{array}$ & Ripk3 $3^{-/-}$ & None & $\begin{array}{l}\text { RIPK3 deficiency increased } \\
\text { survival and decreased } \\
\text { inflammation }\end{array}$ & 39 \\
\hline & $\begin{array}{l}\text { IV injection oleic acid } \\
\text { (rat) }\end{array}$ & Sprague-Dawley & $\mathrm{Nec}-1$ & $\begin{array}{l}\text { Decreased inflammation within } \\
\text { the lung parenchyma }\end{array}$ & 40 \\
\hline \multirow{2}{*}{$\begin{array}{l}\text { Chronic } \\
\text { pulmonary } \\
\text { disease }\end{array}$} & $\begin{array}{l}\text { Cigarette smoking } \\
\text { (mouse) }\end{array}$ & Pink1 ${ }^{-/-}$ & $\mathrm{Nec}-1$ & $\begin{array}{l}\text { Cigarette smoke-induced cell- } \\
\text { death decreased }\end{array}$ & 41 \\
\hline & $\begin{array}{l}\text { Cigarette smoking } \\
\text { (mouse) }\end{array}$ & $\mathrm{BALB} / \mathrm{cByJ}$ & $\mathrm{Nec}-1$ & $\begin{array}{l}\text { Reduced levels of DAMPs and } \\
\text { neutrophils on BAL fluid }\end{array}$ & 42 \\
\hline \multicolumn{6}{|l|}{ Gastrointestinal } \\
\hline \multirow[t]{5}{*}{$\begin{array}{l}\text { Acute liver } \\
\text { injury }\end{array}$} & $\begin{array}{l}\text { Excessive acetaminophen } \\
\text { toxicity (mouse) }\end{array}$ & $\mathrm{C} 57 \mathrm{BL} / 6$ & $\mathrm{Nec}-1$ & $\begin{array}{l}\text { Decreased reactive oxygen } \\
\text { species within the liver }\end{array}$ & 43 \\
\hline & $\begin{array}{l}\text { Excessive acetaminophen } \\
\text { toxicity (mouse) }\end{array}$ & C57BL/6, Ripk3 ${ }^{-/-}$ & $\begin{array}{l}\text { anti-sense } \\
\text { morpholinos }\end{array}$ & $\begin{array}{l}\text { Attenuated necrotic cell death } \\
\text { within livers }\end{array}$ & 44 \\
\hline & $\begin{array}{l}\text { Excessive acetaminophen } \\
\text { toxicity (mouse) }\end{array}$ & Ripk3 $^{-/-}, \mathrm{Mlkl}^{-/-}$ & $\mathrm{Nec}-1$ & $\begin{array}{l}\text { RIPK1 mediated acetaminophen } \\
\text { toxicity independent of } \\
\text { necroptosis }\end{array}$ & 45 \\
\hline & Hepatic IR injury (mouse) & Ripk3 $3^{-/-}$ & Nec-1 & No effect & 46 \\
\hline & $\begin{array}{l}\text { Hepatic IR } \\
\text { injury + hepatic } \\
\text { steatosis (mouse) }\end{array}$ & $\mathrm{Mlkl}^{-/-}$ & None & Protected from hepatic IR injury & 47 \\
\hline \multirow[t]{2}{*}{$\begin{array}{l}\text { Chronic liver } \\
\text { injury }\end{array}$} & $\begin{array}{l}\text { Chronic ethanol feeding } \\
\text { (mouse) }\end{array}$ & $\operatorname{Ripk}^{-1-}$ & $\mathrm{Nec}-1 \mathrm{~s}$ & $\begin{array}{l}\text { RIPK3-deficient mice were } \\
\text { protected but Nec-1s had no } \\
\text { effect }\end{array}$ & 48 \\
\hline & $\begin{array}{l}\text { Gao-binge alcohol } \\
\text { treatment (mouse) }\end{array}$ & $\begin{array}{l}\text { Ripk3 }{ }^{-/} \text {, liver-specific } \\
\text { PSMC1 knockout }\end{array}$ & $\mathrm{Nec}-1$ & $\begin{array}{l}\text { Impaired hepatic proteasome } \\
\text { function by alcohol exposure } \\
\text { led to the accumulation of } \\
\text { RIPK3 }\end{array}$ & 49 \\
\hline \multirow[t]{3}{*}{ Pancreatitis } & $\begin{array}{l}\text { Cerulean-induced acute } \\
\text { pancreatitis (mouse) }\end{array}$ & $M l k l^{-/-}$ & None & $\begin{array}{l}\text { Protected from acute } \\
\text { pancreatitis and necrosis }\end{array}$ & 50 \\
\hline & $\begin{array}{c}\text { Cerulean-induced acute } \\
\text { pancreatitis (mouse) }\end{array}$ & Ripk3-/- & None & $\begin{array}{l}\text { Protected from acute } \\
\text { pancreatitis and necrosis }\end{array}$ & 51 \\
\hline & $\begin{array}{l}\text { Bile acid- and } \\
\text { secretagogue-induced } \\
\text { pancreatitis (mouse) }\end{array}$ & $\mathrm{C} 57 \mathrm{BL} / 6$ & Nec-1 & $\begin{array}{l}\text { Decreased cell injury and severity } \\
\text { of pancreatitis }\end{array}$ & 52 \\
\hline
\end{tabular}


Table 1 (continued)

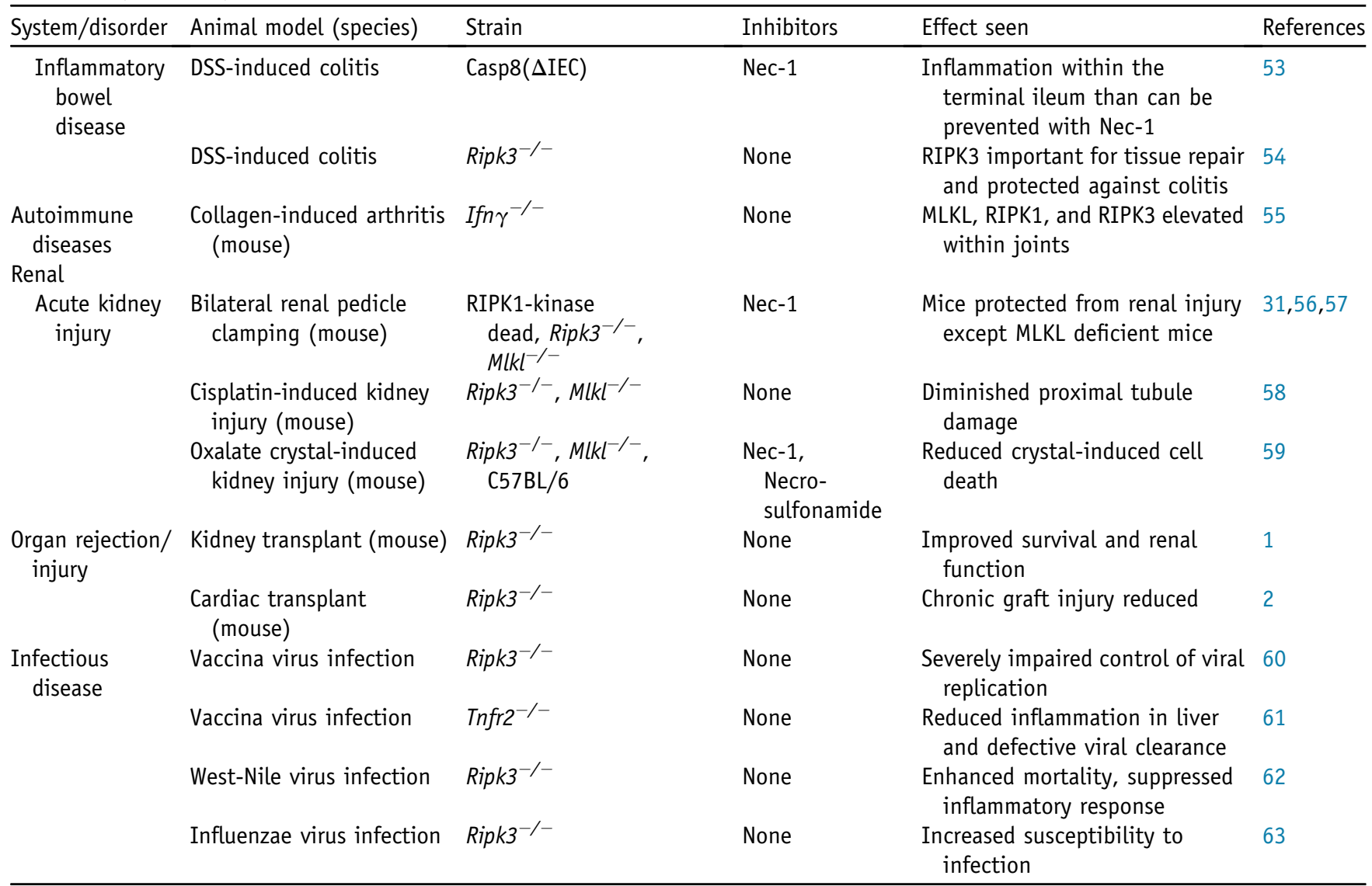

AAA, abdominal aortic aneurysm; BAL, bronchoalveolar lavage; DAMPs, damage-associated molecular pattern molecules; DSS, dextran sodium sulfate; I/R, ischemic reperfusion; LPS, lipopolysaccharide; MLKL, mixed-lineage kinase domain-like protein; PSMC, proteasome 26S subunit, ATPase; RIPK, receptorinteracting protein kinase.

deprived media secreted the anti-inflammatory cytokines IL4 and IL-10. Therefore, targeting necroptosis not only prevents cell death but also manipulates the inflammatory response to a protective type.

\section{Neurodegenerative Diseases}

As the population ages, the prevalence of neurodegenerative diseases will continue to rise. Nonapoptotic cell death has been known to play a role in the development of neurodegenerative diseases. ${ }^{68}$ However, the contribution of necroptosis in pathogenesis and its inhibition as a potential therapeutic modality have only recently been explored. ${ }^{69}$

One of the most commonly studied neurodegenerative diseases is Alzheimer disease (AD). Clinically, AD is characterized by a general cognitive decline that is associated with progressive memory loss and personality disturbances. Pathologically, $\mathrm{AD}$ is understood as the accumulation of incorrectly folded $\beta$-amyloid peptide $(A \beta)$ plaques in the brain and neurofibrillary tangles composed of phosphorylated ${ }_{\tau}$ protein. ${ }^{70}$ The exact mechanisms through which the accumulation of these pathologic protein complexes leads to neuronal loss continue to be investigated. However, a growing body of evidence suggests that necroptosis may play a factor in the pathophysiology of $\mathrm{AD} .^{71,72}$

A previous study by $\mathrm{Li}$ et $\mathrm{al}^{73}$ provided insight on how the formation of $A \beta$ sheet plaques are associated with necroptosis. The authors discovered that the RIPK homotypic interaction motifs mediated the assembly of oligomeric filamentous structures that displayed the characteristics of $A \beta s$. These structures, in turn, were found to be an active signaling complex that mediated necroptosis. Precisely how the kinase activity within these amyloid plaques affects the surrounding extracellular environment (including the possible phosphorylation of $\tau$ ) remains unknown. However, it is known that amyloid structures have the ability to induce inflammation and disrupt membrane integrity in a manner similar to necroptosis. ${ }^{14,74,75}$

Chronic brain inflammation is a hallmark of $\mathrm{AD}$ and is a target of interest for treatment. ${ }^{76}$ Microglia are known to have the capability to uptake and degrade extracellular $\mathrm{A} \beta$ via their autophagic/lysosomal system. ${ }^{77,78}$ Ofengeim et $\mathrm{al}^{32}$ demonstrated a link between RIPK1 and the lysosomal system. The authors discovered that the kinase activity of RIPK1 mediated the up-regulation of Cst7 (a marker for disease-associated microglia), which encodes an endosomal/ 
lysosomal cathepsin inhibitor named cystatin $F$. Inhibition of the endosomal/lysosomal pathway prevents microglia from up-taking deposited $A \beta$ plaques, which leads to subsequent inflammation and cell death within the parenchyma of the brain. In addition, the mice treated with Nec-1s showed significant reductions in $A \beta$ plaque and inflammatory mediators, with an associated attenuation of behavioral deficits. That study highlighted the potential of necroptosis inhibition as a therapeutic modality in AD.

\section{Myocardial Infarction}

Myocardial infarction (MI) is due to coronary artery blockage causing irreversible cell death of cardiomyocytes. Once a diagnosis of MI is made, the primary treatment for the disease is to restore blood flow to the myocardium. However, even restoring blood flow can induce cell injury through a process known as ischemic reperfusion (I/R) injury. $^{79}$

For decades, apoptosis of cardiomyocytes was believed to be the exclusive form of cell death that contributed to the pathophysiology of MI. The potential involvement of necroptosis was first shown by Luedde et al, ${ }^{33}$ who discovered increased levels of RIPK3 in ischemic portions of mouse hearts undergoing left anterior descending coronary artery ligation. In addition, this same group reported better ejection fractions and decreased hypertrophy, accompanied by a diminished inflammatory response, in Ripk $3^{-/}$mice undergoing left anterior descending coronary artery ligation. Further investigation of the role of RIPK3 in cardiac remodeling and I/R revealed that Ripk $3^{-/-}$mice had significant reductions in infarct size in an acute I/R model (30 minutes of ischemia per 4 hours of reperfusion) compared with that in wild-type mice. ${ }^{12}$ Deficiency of RIPK3 also appeared to have long-term cardioprotective effects, because knockout mice showed improvements in hypertrophy, fibrosis, ejection fraction, and mortality compared with wild-type mice up to 8 weeks from left anterior descending coronary artery ligation. Typically, RIPK3 signals through MLKL to achieve necroptosis. However, Zhang et $\mathrm{al}^{12}$ found that in cardiomyocytes, RIPK3 instead signals through CaMKII. This result seems to be inconsistent with the findings from Oerlemans et $\mathrm{al}^{34}$ of significant decreases in MLKL phosphorylation with the use of Nec-1. The exact role of downstream mediators of RIPK1/RIPK3, such as MLKL, within cardiomyocytes continues to be unknown.

Despite the knowledge gap, the inhibition of necroptosis appears to be a strong therapeutic target for achieving cardioprotection from I/R injury after cardiac ischemia. Smith et $\mathrm{al}^{35}$ studied the pharmaceutical benefits of inhibiting necroptosis in mice undergoing cardiac ischemia. The authors found that myocardial cell death and infarct size were inhibited with the use of Nec-1 in mice, suggesting that Nec-1 is cardioprotective in $\mathrm{I} / \mathrm{R}$ injury. It should be noted that in their study, $30 \mu \mathrm{mol} / \mathrm{L}$ of Nec-1 had an apparent cardioprotective effect, but infarct size increased with 100 $\mu \mathrm{mol} / \mathrm{L}$. This finding implies that Nec-1 probably had offtarget effects and may indicate that the inhibition of this pathway may have a narrow therapeutic window.

The cardioprotective effects of Nec-1 have been seen in other studies. ${ }^{34,80}$ The use of necroptosis inhibitors has potential as a cardioprotective agent in MI, but future studies are needed to better elucidate the exact mechanisms and off-target effects of these inhibitors.

\section{Aortic Aneurysm}

Aortic aneurysm is a common vascular disease with a high risk for death if the aneurysm is ruptured. The risk for rupture of an aneurysm is directly correlated with the size of the vessel. However, not all aneurysms warrant repair. Aortic aneurysms should be repaired if they are $>5.5 \mathrm{~cm}$, have rapid expansion, or are symptomatic. ${ }^{81}$ It is recommended that patients with smaller aneurysms not meeting size criteria undergo surveillance, either through annual CT scans or ultrasound studies. There is no pharmacologic treatment available for smaller aortic aneurysms. Current management focuses on controlling hypertension, diabetes, and hyperlipidemia, and smoking cessation. Therefore, the need for pharmacologic treatment has motivated extensive investigations to discover a pharmaceutical target for aortic aneurysms.

Complex pathophysiologic mechanisms lead to the development of aortic aneurysms. Conventionally, apoptosis has been thought of as the form of cell death that primarily contributes to the depletion of medial vascular smooth muscle cells. ${ }^{82,83}$ However, our group discovered that apoptotic inhibitors (caspase inhibitors) were able to prevent the formation of aneurysms but had no effect on aneurysms once already induced. ${ }^{37}$ This finding suggests that apoptosis likely has a significant role only in the formation of aneurysms, but further pathologic degeneration of the aneurysm wall is independent of apoptosis. Preventing the formation of aortic aneurysms would be difficult clinically, and there are currently no markers to predict which patients will develop an aneurysm. Therefore, targeting apoptosis as a preventive measure may have limited application in managing aortic aneurysms.

Our group first suggested necroptosis as an alternative mechanism involved in vascular smooth muscle cells due to the observed high levels of RIPK1 and RIPK3 in human abdominal aortic aneurysm tissues. ${ }^{84}$ In addition, Ripk $3^{-/}$ mice were resistant to aneurysm formation in an elastase model of abdominal aortic aneurysm, which induced aneurysm formation in mice with the infusion of elastase via a catheter within the aorta. ${ }^{36}$ RIPK1 inhibitor, Nec-1s, was used for determining whether necroptosis was a potential therapeutic target in treating small aneurysm progression. ${ }^{37}$ Mice treated with Nec-1s via intraperitoneal injection after elastase perfusion had no aneurysm growth. The DMSO control group had an increase in mean diameter of almost threefold compared with that in the Nec-1s group. The 
benefits are also seen microscopically, where the aortic wall of the Nec-1s-treated group showed improved tissue integrity and reduced markers of inflammation.

Recently, we discovered a novel dual RIPK1/RIPK3 inhibitor, GSK'074. ${ }^{27}$ This dual inhibitor is potent $\left(\mathrm{IC}_{50} 3\right.$ $\mathrm{nmol} / \mathrm{L}$ ), with no detectable cytotoxicity at higher doses, unlike many RIPK3 inhibitors. Aortic expansion was attenuated with the use of GSK'074 in two mouse models of abdominal aortic aneurysm (calcium phosphate and angiotensin II), which may make it a desirable pharmacologic candidate for treating aortic aneurysms not yet meeting surgical criteria.

\section{Pulmonary Diseases}

Acute respiratory distress syndrome is a devastating disease with multiple etiologies. Patients often present with progressive dyspnea, increasing oxygen requirement, and alveolar infiltrates observed on chest imaging after an inciting event. Acute respiratory distress syndrome is thought to be due to a large inflammatory response leading to increased capillary permeability with subsequent fluid accumulation and fibrosis. ${ }^{85}$ Cell death, both systemic and within the lung tissue, has long been thought to contribute to the pathogenesis of this disease. Pan et $\mathrm{al}^{38}$ first demonstrated that the mediators of necroptosis (RIPK1, RIPK3, and MLKL) are up-regulated and activated within the lung tissue of rats being injected i.v. with oleic acid (model of acute respiratory distress syndrome). In a similar study, Wang et $\mathrm{al}^{39}$ induced acute respiratory distress syndrome via intratracheal lipopolysaccharide in both Ripk $^{+/+}$and Ripk $3^{-1-}$ mice. This group found that Ripk $3^{-/-}$mice had a reduction in hypothermia, increased survival, and reductions in cytokines and neutrophils within the lung parenchyma. Pan et $\mathrm{al}^{40}$ evaluated the role of Nec-1 in the treatment of acute respiratory distress syndrome (induced via oleic acid) in rats. Pretreatment with Nec-1 significantly inhibited the inflammatory response by reducing neutrophil infiltration and protein accumulation within the lung.

Chronic obstructive pulmonary disease is a common respiratory condition that affects approximately 5\% of the population. ${ }^{86}$ Multiple studies have demonstrated increased apoptosis within the lungs of patients with chronic obstructive pulmonary disease. ${ }^{87,88}$ In the early 2010 s, necroptosis was found to also play a role in this devastating disease. Mizumura et $\mathrm{al}^{41}$ were the first to suggest that necroptosis contributes to the pathogenesis of chronic obstructive pulmonary disease through the activation of RIPK3 and autophagy-dependent elimination of mitochondria induced by cigarette smoke in cultured pulmonary epithelial cells. The investigators also demonstrated that cigarette smoke-induced cell death could be reduced via necroptosis inhibitors. Furthermore, they discovered elevated levels of RIPK3 within the lung tissue of patients with chronic obstructive pulmonary disease. Pouwels et $\mathrm{al}^{42}$ subsequently found that mice exposed to cigarette smoke in the presence of Nec-1 had significantly reduced levels of damage-associated molecular pattern molecules, endogenous molecules that are released and trigger inflammation upon tissue damage, and of neutrophils within the bronchoalveolar lavage fluid.

\section{Liver Injury}

Liver failure can be classified as either acute or chronic. Acute liver failure is characterized by acute liver injury, hepatic encephalopathy, and an elevated international normalized ratio, ${ }^{89}$ whereas chronic liver failure is usually asymptomatic until decompensation occurs. ${ }^{90}$ Various etiologies that can lead to acute or chronic liver failure have been identified. However, how necroptosis influences the pathophysiology of liver injury is ambiguous.

Acetaminophen toxicity is a well-established mouse model for the study of acute liver injury. ${ }^{91}$ Takemoto et $\mathrm{al}^{43}$ demonstrated that phosphorylation of Ripk1 was elevated in mice that were given excessive acetaminophen. They also found that reactive oxygen species levels were decreased with the use of Nec-1 in the mice given excessive acetaminophen. Furthermore, Ramachandran et $\mathrm{al}^{44}$ found that RIPK3 is an early mediator of acetaminophen toxicity, possibly through the inhibition of the translocation of dynamin-related protein 1 , the initiator of mitochondrial fission. However, not all studies utilizing the acetaminophen toxicity model in $\mathrm{Ripk}^{-1-}$ and $\mathrm{Mlkl}^{--}$mice have found a protective phenotype against acute liver injury compared with wild-type mice. ${ }^{45}$ Additionally, the findings from these studies suggest that RIPK1-mediated acetaminophen toxicity is independent of necroptosis. ${ }^{45,92} \mathrm{Li}$ et $\mathrm{al}^{25}$ reported that acetaminophen-induced necroptosis in human hepatocytes was reduced with dabrafenib through its ability to inhibit RIPK3. Therefore, it is possible that the beneficial effects seen with dabrafenib are related to off-target effects other than RIPK3. Given the inconsistent results, how necroptosis and its mediators function in acetaminopheninduced hepatotoxicity remains debatable.

$\mathrm{I} / \mathrm{R}$ injury of the liver has also been a concern in various clinical settings (eg, liver transplant and shock liver). Necroptosis has been shown to have a role in the pathogenesis of various organ systems, and treatment targeting the mediators of necroptosis has been found to be beneficial. Unfortunately, Saeed et $\mathrm{al}^{46}$ found that the expression of RIPK1, RIPK3, and MLKL were unchanged in the hepatic I/R injury model. Additionally, the Ripk ${ }^{-1-}$ status of mice and pretreatment with Nec-1s in wild-type mice were not protective against liver injury in the hepatic I/R model. In contrast, Ni et al ${ }^{47}$ found that in the setting of hepatic steatosis, $M l k l^{-/-}$mice were protected from hepatic IR injury.

Necroptosis has also been shown to play a role in chronic liver injury. One of the most common causes of chronic liver injury in the United States is excessive alcohol consumption. ${ }^{93}$ Roychowdhury et $\mathrm{al}^{48}$ were the first to establish that elevated levels of RIPK3 were present within the livers of both humans with alcoholic liver disease and mice after 
long-term ethanol feeding. Furthermore, they discovered that RIPK3 expression in the setting of chronic ethanol consumption was CYP2E1 dependent. Interestingly, Ripk $3^{-l-}$ mice were protected from ethanol-induced hepatocyte injury, but treatment with Nec-1s had no effect. Therefore, chronic ethanol injury is independent of RIPK1. Subsequently, Wang et $\mathrm{al}^{94}$ used the Gao-binge alcohol treatment model, which is thought to mimic alcoholic liver injury in patients with chronic alcohol abuse and a bingedrinking history. ${ }^{49}$ Their study revealed that levels of proteasome subunit $\alpha 2$ and proteasome 26S subunit, ATPase 1, which are essential in the proteolytic degradation of most intracellular proteins, were decreased with Gao-binge treatment. Pharmacologic or genetic inhibition of these proteins led to the accumulation of RIPK3 within mouse livers, and a similar finding was observed in human livers. They concluded that impaired hepatic proteasome function by alcohol exposure may lead to an accumulation of RIPK3.

Taken together, these studies show that the precise mechanism contributing to the pathogenesis of liver injury remains unclear. If necroptosis participates in liver injury, its role is likely to be limited to certain etiologies.

\section{Pancreatitis}

Acute pancreatitis is a relatively common inflammatory disease with multiple etiologies. Treatment is focused on resuscitation and elimination of the driving etiology, when possible. Currently, no pharmacologic treatment has been shown to be beneficial in reducing the severity of pancreatitis in these patients. Although most patients recover without complications, a subset of patients develop severe pancreatitis, with associated pancreatic necrosis, which can lead to significant morbidity and mortality. ${ }^{95}$

Previous studies have shown that ipk $^{-1-}$ and $M l k l^{-1-}$ mice exhibited a reduction in cell death in the pancreas on induction of pancreatitis. ${ }^{50,51}$ Louhimo et al ${ }^{52}$ subsequently used two experimental mouse models of severe pancreatitis (induced by bile acid and secretagogue) for examining the role of necroptosis in acinar cell death. The studies found that necroptosis was the most prevalent mode of acinar cell death, with little to no apoptosis involved. Acinar cell death was preventable via the administration of Nec-1 or Ripk 3 deletion, which subsequently reduced the severity of pancreatitis. Interestingly, cell injury was reduced with Nec-1 even after the disease process was already established.

Necroptosis appears to play a pivotal role in the pathophysiology of pancreatitis. However, more studies are needed to better understand how other inhibitors of necroptosis compare with $\mathrm{Nec}-1$ in these mouse models of pancreatitis.

\section{Inflammatory Bowel Disease}

Inflammatory bowel disease (IBD) is a debilitating disease with various clinical presentations. IBD is characterized by various degrees of inflammation within the bowel wall. Currently available medical treatments for IBD include oral 5-aminosalicylates, glucocorticoids, immunomodulators, and biologic therapies. Although these therapies can be effective, they have been associated with frequent and severe side effects.

The etiology of IBD remains largely unknown. It is generally accepted that IBD is driven by complex interactions between genetics, the environment, and the microbiome. ${ }^{96}$ Apoptosis and necrosis have been extensively studied in IBD. However, investigations into the role of necroptosis in IBD have only recently begun. Necroptosis was first identified as playing a possible role in the pathogenesis of Crohn disease by Günther et al. ${ }^{53}$ This group utilized a conditional deletion of caspase- 8 in intestinal epithelial cells and found that mice developed spontaneous inflammatory lesions within the terminal ileum. Furthermore, intestinal epithelial cell death induced by TNF- $\alpha$ was associated with an increased expression of RIPK3. In addition, they identified increased expression of RIPK 3 and cell death within the terminal ileum of patients with Crohn disease.

Subsequently, Pierdomenico et $\mathrm{al}^{97}$ examined the pathologic intestinal tissue of children with IBD. The study looked at samples from healthy controls, Crohn disease, ulcerative colitis, and allergic colitis. On Western blots, levels of RIPK3 and MLKL were significantly increased in these tissues compared to those in healthy controls, suggesting a possible association between the two. This group also used HT29 cells, a colon cancer cell line, and showed that Nec-1 apparently protected cells against necroptosis induced via a combination of interferon (IFN)- $\gamma$, zFAD-fmk (z-VAD), and doxorubicin. Recently, Negroni et $\mathrm{al}^{98}$ discovered that activation of necroptosis within intestinal cell lines led to increased production of inflammatory molecules, such as IL-1 $\beta$, IL-8, and IL-33, and altered the intestinal mucosa permeability via the loss of cell-to-cell adhesion molecules. Treatment of these cells with Nec-1 led to significant reductions in both inflammatory mediators and damage to the intestinal barrier. However, the above studies contradict the findings set forth by Moriwaki et al. ${ }^{54}$ This group found that RIPK3 was protective against dextran sodium sulfate-induced colitis (a mouse model of ulcerative colitis) through IL-22 expression. ${ }^{54}$ That study highlighted that RIPK3 was important for tissue repair and controlled a necrosis-independent pathway of inflammation by regulating cytokine expression in DCs. It is likely that necroptosis, along with its mediators, must exist in a physiologic equilibrium to maintain healthy bowel wall.

\section{Autoimmune Diseases}

Autoimmune disease encompasses a variety of pathologic entities. The basis behind these diseases is a dysregulated attack of the immune system on self-antigens. Necroptosis has been shown to be associated with two common 
autoimmune disorders via sterile inflammation: psoriasis and rheumatoid arthritis. Currently, GSK2982772 is being tested in clinical trials in both psoriasis and rheumatoid arthritis. $^{23}$

Psoriasis is an autoimmune skin disorder characterized by erythematous papules and scaly plaques. Current treatments can be classified as either topical or systemic. The most common topical treatments used are corticosteroids and vitamin D analogues. ${ }^{99}$ However, patients with severe disease often require systemic treatment, such as methotrexate, cyclosporine, and infliximab. ${ }^{100}$ Although these systemic treatments can be effective, they have been associated with many undesired side effects. ${ }^{101}$

Psoriasis is thought to be initiated through myeloid DCs that release TNF- $\alpha$ and IL-23, which subsequently activate T-helper cells. ${ }^{102,103}$ The T-helper cells then activate epidermal keratinocytes and recruit immune cells within the psoriatic lesion, causing a dysregulated immune response. ${ }^{104}$ However, the driving pathologic mechanisms may be more complicated than was originally thought. Saito et $\mathrm{al}^{105}$ analyzed skin samples of psoriatic lesions from patients and found that RIPK1 expression in keratinocytes was decreased compared to that in normal epidermis. In addition, the cytokines involved in the pathophysiology of psoriasis were found to be able to reduce RIPK1 expression in human epidermal keratinocytes in vitro. Furthermore, they found that RIPK1 down-regulation within these keratinocytes increased their susceptibility to TNF-related apoptosis-inducing ligand, which is essential in the pathogenesis of psoriasis.

Rheumatoid arthritis is a devastating systemic autoimmune disorder that leads to peripheral polyarthritis. Rheumatoid arthritis causes severe destruction within the joints, leading to physical deformities and loss of function. ${ }^{106}$ Treatments for rheumatoid arthritis are primarily systemic and consist of a variety of different pharmacologic agents focused on targeting inflammation and decreasing the hyperimmune response within patients. These treatments consist of nonsteroidal anti-inflammatory drugs, glucocorticoids, and disease-modifying antirheumatic drugs. ${ }^{107}$ Previous studies have linked necroptosis and inflammation. RIPK3 can activate the formation of the inflammasome and the subsequent release of cytokines. ${ }^{108,109}$ Alternatively, IFN- $\gamma$ suppresses the inflammatory response and has been found to be protective in autoimmune disorders. ${ }^{110}$ Lee et al $^{55}$ investigated whether IFN- $\gamma$ had protective effects in autoimmune arthritis by regulating necroptosis. They found that IFN- $\gamma$ downregulated necroptosis and the expression of MLKL, whereas the loss of IFN- $\gamma$ increased the expression of MLKL and promoted necroptosis. Furthermore, they found that MLKL, RIPK1, and RIPK3 were increased in the joints of mice with collagen-induced arthritis, which was exacerbated in Ifn- $\gamma^{-1-}$ mice. This finding suggests that IFN- $\gamma$ may have a potential use in the treatment of rheumatoid arthritis through necroptosis.

\section{Acute Kidney Injury}

Acute kidney injury (AKI) is an abrupt reduction in kidney function associated with a rise in serum creatinine, decreased urine output, and accumulation of metabolic toxins. ${ }^{111}$ There are a variety of causes of an AKI, which can be classified based on the level of injury: prerenal (inability to perfuse the kidneys), intrinsic renal (pathologic process occurring within the kidneys), and postrenal (due to inadequate drainage of the genitourinary system). Proteins essential in the necroptosis pathway have been found to contribute to the pathogenesis of the prerenal and intrinsic renal kidney classifications of AKI. Although there could be a role for necroptosis in postrenal AKI, this has not been studied.

Several studies have investigated the role of necroptosis in kidney injury via bilateral renal pedicle clamping (prerenal). These studies have revealed that RIPK1 kinase-dead mice, mice treated with $\mathrm{Nec}-1$, and $R i p k 3^{-1-}$ mice were all protected from renal injury, mainly through attenuation of the effects of I/R injury. ${ }^{31,56,57}$ However, the same protective effect was not found in $M l k l^{-1-}$ mice. ${ }^{31}$ Therefore, it may be that the mediators of necroptosis (RIPK1 and RIPK3) play a role outside of necroptosis with regard to prerenal injury. Other disease models have been used for investigating the role of necroptosis with regard to intrinsic renal injury. ${ }^{58,59,112}$ Interestingly, deficiency in MLKL appears to have a similar protective effect in these disease models compared with the effect in Ripk $3^{-/-}$mice; this finding suggests that in contrast to prerenal injury, necroptosis plays a larger role in intrinsic renal injury.

Other forms of regulated necrosis have been shown to play a role in AKI. ${ }^{13}$ All of these forms of necrosis are known to create a proinflammatory environment, which can further drive necrosis and lead to progression of renal injury. ${ }^{114}$ Thus, even though necroptosis may not be the sole pathophysiologic process leading to AKI, other forms of necrosis, in addition to the mediators of necroptosis, appear to play a significant role.

\section{Organ Transplant}

Over the past 50 years, the field of solid organ transplantation has evolved tremendously. Advancements in surgical technique, patient and organ selection, organ preservation, and immunosuppressant medications have led to prolonged survival and improvements in quality of life in transplant recipients. Although great success has been achieved in improving the rates of rejection and dysfunction in patients receiving immunosuppressant medications, these medications have been associated with severe and lifethreatening side effects. ${ }^{115}$ Therefore, a significant amount of research has focused on identifying a new target with a safer therapeutic profile.

A landmark study conducted by Lau et $\mathrm{al}^{1}$ found that necroptosis played a significant role in reducing allograft 
survival in a murine kidney transplant model. In that study, silencing of caspase-8 with hairpin RNA was used in donor C57BL/6 mouse kidneys, and it was found that silencing caspase-8 increased necroptosis and accelerated rejection. In addition, the transplantation of Ripk3 $3^{-/-}$kidneys led to improved survival and renal function compared with those in controls. Kwok et $\mathrm{al}^{2}$ also found that necroptosis plays a significant role in chronic cardiac allograft rejection as well. Using a murine cardiac allograft transplantation model, the group found that $\mathrm{CD} 4^{+} \mathrm{T}$-cell-mediated cardiac rejection was inhibited by $R i p k 3^{-1-}$ donors.

Although the exact role of necroptosis in the rejection of allografts still needs to be elucidated, the findings from the available studies are promising. Ripk $3^{-/-}$mice do not have an immunodeficient phenotype. Thus, inhibiting necroptosis can potentially provide a safer therapeutic profile than those of the current immunomodulatory drugs.

\section{Infectious Disease}

In general, necroptosis has been shown to contribute to the pathogenesis of various diseases. However, there are instances in which necroptosis can be beneficial to the host/ organism since it may be an alternative host defense mechanism against infection, particularly viral infections. Viruses are obligate intracellular pathogens that have evolved mechanisms for evading host immune responses and hijacking the replication machinery of cells for propagation. Therefore, viruses require that cells remain alive long enough to complete their life cycle. In response to viral infections, host cells release a variety of chemokines and cytokines to generate a nonsterile inflammatory response and to prime surrounding cells.

Apoptosis is a mechanism essential to hosts for the elimination of pathogens by sacrificing infected cells. Many viruses have evolved mechanisms that inhibit caspase-mediated apoptosis (eg, viral inhibitors of apoptosis). In the case of failed apoptosis, necroptosis is a necessary alternative way to eliminate these viruses. ${ }^{116}$ However, the importance of inhibiting necroptosis by viruses continues to remain undefined. Studies using vaccinia virus have shed some light on this mystery. Ripk $3^{-/-}$mice infected with vaccinia virus are much more susceptible to death compared to WT mice ${ }^{60,61}$ In addition, these mice are not able to generate an appropriate inflammatory response to infection, suggesting that necroptosis is crucial for generating an antiviral response within the host. ${ }^{62}$ Therefore, the role of necroptosis mediators appears to be multifactorial.

Influenza A virus-infected bone marrow-derived macrophages do not die but instead promote the generation of IFN- $\beta{ }^{63}{ }^{2 i p k} 3^{-1-}$ mice have attenuated levels of IFN- $\beta$, which may contribute to their susceptibility to influenza infection. Similarly, West-Nile virus-infected neurons have been shown to promote neuroinflammation independent of cell death. ${ }^{62}$ Ripk $^{-/-}$neurons are unable to secrete the levels of cytokines necessary for attracting lymphocytes, leading to propagation of the virus within these cells.

The mediators of necroptosis appear to play a very significant role within the host in regard to controlling viral infections. These mediators are able to limit viral replication by either promoting cell death or generating an immune response. The aforementioned studies indicate that when any of these components is jeopardized, a virus is more capable of propagating within a host. ${ }^{60-63,116}$

\section{Conclusion}

Necroptosis is a newly discovered cell death pathway that is mediated by RIPK3 and other intracellular signaling molecules. Preclinical studies have revealed an important role of necroptosis in a variety of disease processes. Inhibition of necroptosis has been reported to be beneficial in mice. At least one necroptosis inhibitor has been advanced to human clinical trials, but its efficacy in humans has yet to be demonstrated. Continued research, including the discovery of novel inhibitors or the identification of new regulatory molecules, will likely prove that targeting necroptosis is an effective and viable approach to treating many diseases.

\section{Acknowledgments}

We thank the editorial team at the University of WisconsinMadison, for their assistance in the preparation of the manuscript, specifically Dana Maya and Molly Wesling.

\section{References}

1. Lau A, Wang S, Jiang J, Haig A, Pavlosky A, Linkermann A, Zhang ZX, Jevnikar AM: RIPK3-mediated necroptosis promotes donor kidney inflammatory injury and reduces allograft survival. Am J Transplant 2013, 13:2805-2818

2. Kwok C, Pavlosky A, Lian D, Jiang J, Huang X, Yin Z, Liu W, Haig A, Jevnikar AM, Zhang ZX: Necroptosis is involved in CD4+T cell-mediated microvascular endothelial cell death and chronic cardiac allograft rejection. Transplantation 2017, 101:2026-2037

3. Gupta K, Phan N, Wang Q, Liu B: Necroptosis in cardiovascular disease - a new therapeutic target. J Mol Cell Cardiol 2018, 118: 26-35

4. Lin Y, Devin A, Rodriguez Y, Liu ZG: Cleavage of the death domain kinase RIP by caspase- 8 prompts TNF-induced apoptosis. Genes Dev $1999,13: 2514-2526$

5. Feng S, Yang Y, Mei Y, Ma L, Zhu DE, Hoti N, Castanares M, Wu M: Cleavage of RIP3 inactivates its caspase-independent apoptosis pathway by removal of kinase domain. Cell Signal 2007, 19:2056-2067

6. Moriwaki K, Chan FK: RIP3: a molecular switch for necrosis and inflammation. Genes Dev 2013, 27:1640-1649

7. Mandal P, Berger SB, Pillay S, Moriwaki K, Huang C, Guo H, Lich JD, Finger J, Kasparcova V, Votta B, Ouellette M, King BW, Wisnoski D, Lakdawala AS, DeMartino MP, Casillas LN, Haile PA, Sehon CA, Marquis RW, Upton J, Daley-Bauer LP, Roback L, Ramia N, Dovey CM, Carette JE, Chan FK, Bertin J, Gough PJ, Mocarski ES, Kaiser WJ: RIP3 induces apoptosis independent of pronecrotic kinase activity. Mol Cell 2014, 56:481-495 
8. Christofferson DE, Yuan J: Necroptosis as an alternative form of programmed cell death. Curr Opin Cell Biol 2010, 22:263-268

9. Sun L, Wang H, Wang Z, He S, Chen S, Liao D, Wang L, Yan J, Liu W, Lei X, Wang X: Mixed lineage kinase domain-like protein mediates necrosis signaling downstream of RIP3 kinase. Cell 2012, 148:213-227

10. Wang H, Sun L, Su L, Rizo J, Liu L, Wang LF, Wang FS, Wang X: Mixed lineage kinase domain-like protein MLKL causes necrotic membrane disruption upon phosphorylation by RIP3. Mol Cell 2014, $54: 133-146$

11. Wang Z, Jiang $H$, Chen S, Du F, Wang X: The mitochondrial phosphatase PGAM5 functions at the convergence point of multiple necrotic death pathways. Cell 2012, 148:228-243

12. Zhang T, Zhang Y, Cui M, Jin L, Wang Y, Lv F, Liu Y, Zheng W, Shang H, Zhang J, Zhang M, Wu H, Guo J, Zhang X, Hu X, Cao CM, Xiao RP: CaMKII is a RIP3 substrate mediating ischemia- and oxidative stress-induced myocardial necroptosis. Nat Med 2016, 22:175-182

13. Wallach D, Kang TB, Kovalenko A: Concepts of tissue injury and cell death in inflammation: a historical perspective. Nat Rev Immunol 2014, 14:51-59

14. Pasparakis M, Vandenabeele P: Necroptosis and its role in inflammation. Nature 2015, 517:311-320

15. Lawlor KE, Khan N, Mildenhall A, Gerlic M, Croker BA, D'Cruz AA, Hall C, Kaur Spall S, Anderton H, Masters SL, Rashidi M, Wicks IP, Alexander WS, Mitsuuchi Y, Benetatos CA, Condon SM, Wong WW, Silke J, Vaux DL, Vince JE: RIPK3 promotes cell death and NLRP3 inflammasome activation in the absence of MLKL. Nat Commun 2015, 6:6282

16. Kang TB, Yang SH, Toth B, Kovalenko A, Wallach D: Caspase-8 blocks kinase RIPK3- mediated activation of the NLRP3 inflammasome. Immunity 2013, 38:27-40

17. Degterev A, Hitomi J, Germscheid M, Ch'en IL, Korkina O, Teng X, Abbott D, Cuny GD, Yuan C, Wagner G, Hedrick SM, Gerber SA, Lugovskoy A, Yuan J: Identification of RIP1 kinase as a specific cellular target of necrostatins. Nat Chem Biol 2008, 4:313-321

18. Xie T, Peng W, Yan C, Wu J, Gong X, Shi Y: Structural insights into RIP3-mediated necroptotic signaling. Cell Rep 2013, 5:70-78

19. Degterev A, Maki JL, Yuan J: Activity and specificity of necrostatin-1, small-molecule inhibitor of RIP1 kinase. Cell Death Differ 2013, 20:366

20. Muller AJ, DuHadaway JB, Donover PS, Sutanto-Ward E, Prendergast GC: Inhibition of indoleamine 2,3-dioxygenase, an immunoregulatory target of the cancer suppression gene Bin1, potentiates cancer chemotherapy. Nat Med 2005, 11:312-319

21. Teng X, Degterev A, Jagtap P, Xing X, Choi S, Denu R, Yuan J, Cuny GD: Structure- activity relationship study of novel necroptosis inhibitors. Bioorg Med Chem Lett 2005, 15:5039-5044

22. Harris PA, Berger SB, Jeong JU, Nagilla R, Bandyopadhyay D, Campobasso N, et al: Discovery of a first-in-class receptor interacting protein 1 (RIP1) kinase specific clinical candidate (GSK2982772) for the treatment of inflammatory diseases. J Med Chem 2017, 60:1247-1261

23. Weisel K, Scott NE, Tompson DJ, Votta BJ, Madhavan S, Povey K, Wolstenholme A, Simeoni M, Rudo T, Richards-Peterson L, Sahota T, Wang JG, Lich J, Finger J, Verticelli A, Reilly M, Gough PJ, Harris PA, Bertin J, Wang ML: Randomized clinical study of safety, pharmacokinetics, and pharmacodynamics of RIPK1 inhibitor GSK2982772 in healthy volunteers. Pharmacol Res Perspect 2017, 5:6

24. Kaiser WJ, Sridharan H, Huang C, Mandal P, Upton JW, Gough PJ, Sehon CA, Marquis RW, Bertin J, Mocarski ES: Toll-like receptor 3mediated necrosis via TRIF, RIP3, and MLKL. J Biol Chem 2013, 288:31268-31279

25. Li JX, Feng JM, Wang Y, Li XH, Chen XX, Su Y, Shen YY, Chen Y, Xiong B, Yang CH, Ding J, Miao ZH: The B-RafV600Einhibitor dabrafenib selectively inhibits RIP3 and alleviates acetaminopheninduced liver injury. Cell Death Dis 2014, 5:e1278

26. Fauster A, Rebsamen M, Huber KV, Bigenzahn JW, Stukalov A, Lardeau CH, Scorzoni S, Bruckner M, Gridling M, Parapatics K,
Colinge J, Bennett KL, Kubicek S, Krautwald S, Linkermann A, Superti-Furga G: A cellular screen identifies ponatinib and pazopanib as inhibitors of necroptosis. Cell Death Dis 2015, 6:e1767

27. Zhou T, Wang Q, Phan N, Ren J, Yang H, Feldman CC, Feltenberger JB, Ye Z, Wildman SA, Tang W, Liu B: Identification of a novel class of RIP1/RIP3 dual inhibitors that impede cell death and inflammation in mouse abdominal aortic aneurysm models. Cell Death Dis 2019, 10:226

28. Newton K, Dugger DL, Wickliffe KE, Kapoor N, De Almagro MC, Vucic D, Komuves L, Ferrando RE, French DM, Webster J, RooseGirma M, Warming S, Dixit VM: Activity of protein kinase RIPK3 determines whether cells die by necroptosis or apoptosis. Science 2014, 343:1357-1360

29. Polykratis A, Hermance N, Zelic M, Roderick J, Kim C, Van T-M, Lee TH, Chan FK, Pasparakis M, Kelliher MA: Cutting edge: RIPK1 kinase inactive mice are viable and protected from TNF-induced necroptosis in vivo. J Immunol 2014, 193:1539-1543

30. Degterev A, Huang Z, Boyce M, Li Y, Jagtap P, Mizushima N, Cuny GD, Mitchison TJ, Moskowitz MA, Yuan J: Chemical inhibitor of nonapoptotic cell death with therapeutic potential for ischemic brain injury. Nat Chem Biol 2005, 2:112-119

31. Newton K, Dugger DL, Maltzman A, Greve JM, Hedehus M, MartinMcnulty B, Carano RA, Cao TC, Van Bruggen N, Bernstein L, Lee WP, Wu X, Devoss J, Zhang J, Jeet S, Peng I, McKenzie BS, Roose-Girma M, Caplazi P, Diehl L, Webster JD, Vucic D: RIPK3 deficiency or catalytically inactive RIPK1 provides greater benefit than MLKL deficiency in mouse models of inflammation and tissue injury. Cell Death Differ 2016, 23:1565-1576

32. Ofengeim D, Mazzitelli S, Ito Y, DeWitt JP, Mifflin L, Zou C, Das S, Adiconis X, Chen H, Zhu H, Kelliher MA, Levin JZ, Yuan J: RIPK1 mediates a disease-associated microglial response in Alzheimer's disease. Proc Natl Acad Sci 2017, 41:8788-8797

33. Luedde M, Lutz M, Carter N, Sosna J, Jacoby C, Vucur M, Gautheron J, Roderburg C, Borg N, Reisinger F, Hippe HJ, Linkermann A, Wolf MJ, Rose-John S, Lüllmann-Rauch R, Adam D, Flögel U, Heikenwalder M, Luedde T, Frey N: RIP3, a kinase promoting necroptotic cell death, mediates adverse remodelling after myocardial infarction. Cardiovasc Res 2014, 103: 206-216

34. Oerlemans MI, Liu J, Arslan F, Den Ouden K, Van Middelaar BJ, Doevendans PA, Sluijter JP: Inhibition of RIP1-dependent necrosis prevents adverse cardiac remodeling after myocardial ischemiareperfusion in vivo. Basic Res Cardiol 2012, 107:270

35. Smith CC, Davidson SM, Lim SY, Simpkin JC, Hothersall JS, Yellon DM: Necrostatin: a potentially novel cardioprotective agent? Cardiovasc Drugs Ther 2007, 21:227-233

36. Pyo R, Lee JK, Shipley JM, Curci JA, Mao D, Ziporin SJ, Ennis TL, Shapiro SD, Senior RM, Thompson RW: Targeted gene disruption of matrix metalloproteinase-9 (gelatinase B) suppresses development of experimental abdominal aortic aneurysms. J Clin Invest 2000, 105: $1641-1649$

37. Wang Q, Zhou T, Liu Z, Ren J, Phan N, Gupta K, Stewart DM, Morgan S, Assa C, Kent KC, Liu B: Inhibition of ReceptorInteracting Protein Kinase 1 with Necrostatin-1s ameliorates disease progression in elastase-induced mouse abdominal aortic aneurysm model. Sci Rep 2017, 7:42159

38. Pan L, Yao D, Yu YZ, Chen BJ, Li SJ, Xi C, Wang ZH, Li JH, Long J, Tu YS: Activation of necroptosis in a rat model of acute respiratory distress syndrome induced by oleic acid. Am J Physiol Lung Cell Mol Physiol 2016, 68:661-668

39. Wang L, Wang T, Li H, Liu Q, Zhang Z, Xie W, Feng Y, Socorburam T, Wu G, Xia Z, Wu Q: Receptor interacting protein 3mediated necroptosis promotes lipopolysaccharide- induced inflammation and acute respiratory distress syndrome in mice. PLoS One 2016, 11:e0155723

40. Pan L, Yao DC, Yu YZ, Li SJ, Chen BJ, Hu GH, Xi C, Wang ZH, Wang HY, Li JH, Tu YS: Necrostatin-1 protects against oleic acid- 
induced acute respiratory distress syndrome in rats. Biochem Biophys Res Commun 2016, 478:1602-1608

41. Mizumura K, Cloonan SM, Nakahira K, Bhashyam AR, Cervo M, Kitada T, Glass K, Owen CA, Mahmood A, Washko GR, Hashimoto S, Ryter SW, Choi AM: Mitophagy- dependent necroptosis contributes to the pathogenesis of COPD. J Clin Invest 2014, 124:3987-4003

42. Pouwels SD, Zijlstra GJ, van der Toorn M, Hesse L, Gras R, ten Hacken NH, Krysko DV, Vandenabeele P, de Vries M, van Oosterhout AJM, Heijink IH, Nawijn MC: Cigarette smoke-induced necroptosis and DAMP release trigger neutrophilic airway inflammation in mice. Am J Physiol Cell Mol Physiol 2015, 310:377-386

43. Takemoto K, Hatano E, Iwaisako K, Takeiri M, Noma N, Ohmae S, Toriguchi K, Tanabe K, Tanaka H, Seo S, Taura K, Machida K, Takeda N, Saji S, Uemoto S, Asagiri M: Necrostatin-1 protects against reactive oxygen species (ROS)-induced hepatotoxicity in acetaminophen-induced acute liver failure. FEBS Open Bio 2014, 4:777-787

44. Ramachandran A, Mcgill MR, Xie Y, Ni HM, Ding WX, Jaeschke H: Receptor interacting protein kinase 3 is a critical early mediator of acetaminophen-induced hepatocyte necrosis in mice. Hepatology 2013, 58:2099-2108

45. Dara L, Johnson H, Suda J, Win S, Gaarde W, Han D, Kaplowitz N: Receptor interacting protein kinase 1 mediates murine acetaminophen toxicity independent of the necrosome and not through necroptosis. Hepatology 2015, 62:1847-1857

46. Saeed WK, Jun DW, Jang K, Chae YJ, Lee JS, Kang HT: Does necroptosis have a crucial role in hepatic ischemia-reperfusion injury? PLoS One 2017, 12:e184752

47. Ni HM, Chao X, Kaseff J, Deng F, Wang S, Shi YH, Li T, Ding WX, Jaeschke H: Receptor-interacting serine/threonine-protein kinase 3 (RIPK3)-mixed lineage kinase domain-like protein (MLKL)mediated necroptosis contributes to ischemia-reperfusion injury of steatotic livers. Am J Pathol 2019, 189:1363-1374

48. Roychowdhury S, Mcmullen MR, Pisano SG, Liu X, Nagy LE: Absence of receptor interacting protein kinase 3 prevents ethanolinduced liver injury. Hepatology 2013, 5:1773-1783

49. Bertola A, Mathews S, Ki SH, Wang H, Gao B: Mouse model of chronic and binge ethanol feeding (the NIAAA model). Nat Protoc 2013, 8:627-637

50. Wu J, Huang Z, Ren J, Zhang Z, He P, Li Y, Ma J, Chen W, Zhang Y, Zhou X, Yang Z, Wu SQ, Chen L, Han J: Mlkl knockout mice demonstrate the indispensable role of Mlkl in necroptosis. Cell Res 2013, 23:994-1006

51. He S, Wang L, Miao L, Wang T, Du F, Zhao L, Wang X: Receptor interacting protein kinase-3 determines cellular necrotic response to TNF- $\alpha$. Cell 2009, 137:1100-1111

52. Louhimo JM, Steer ML, Perides G: Necroptosis is an important severity determinant and potential therapeutic target in experimental severe pancreatitis. Cell Mol Gastroenterol Hepatol 2016, 2: 519-535

53. Günther C, Martini E, Wittkopf N, Amann K, Weigmann B, Neumann H, Waldner MJ, Hedrick SM, Tenzer S, Neurath MF, Becker C: Caspase-8 regulates TNF- $\alpha$-induced epithelial necroptosis and terminal ileitis. Nature 2011, 477:335-339

54. Moriwaki K, Balaji S, McQuade T, Malhotra N, Kang J, Chan FK: The necroptosis adaptor RIPK3 promotes injury-induced cytokine expression and tissue repair. Immunity 2014, 41:567-578

55. Lee SH, Kwon JY, Kim SY, Jung KA, Cho ML: Interferon-gamma regulates inflammatory cell death by targeting necroptosis in experimental autoimmune arthritis. Sci Rep 2017, 7:10133

56. Linkermann A, De Zen F, Weinberg J, Kunzendorf U, Krautwald S: Programmed necrosis in acute kidney injury. Nephrol Dial Transplant 2012, 27:3412-3419

57. Linkermann A, Brasen JH, Darding M, Jin MK, Sanz AB, Heller J-O, De Zen F, Weinlich R, Ortiz A, Walczak H, Weinberg JM, Green DR, Kunzendorf U, Krautwald S: Two independent pathways of regulated necrosis mediate ischemia-reperfusion injury. Proc Natl Acad Sci 2013, 110:12024-12029
58. Xu Y, Ma H, Shao J, Wu J, Zhou L, Zhang Z, Wang Y, Huang Z, Ren J, Liu S, Chen X, Han J: A role for tubular necroptosis in cisplatin-induced AKI. J Am Soc Nephrol 2015, 26:2647-2658

59. Mulay SR, Desai J, Kumar SV, Eberhard JN, Thomasova D, Romoli S, Grigorescu M, Kulkarni OP, Popper B, Vielhauer V, Zuchtriegel G, Reichel C, Bräsen JH, Romagnani P, Bilyy R, Munoz LE, Herrmann M, Liapis H, Krautwald S, Linkermann A, Anders HJ: Cytotoxicity of crystals involves RIPK3-MLKL-mediated necroptosis. Nat Commun 2016, 7:10274

60. Cho YS, Challa S, Moquin D, Genga R, Ray TD, Guildford M, Chan FK: Phosphorylation-driven assembly of the RIP1-RIP3 complex regulates programmed necrosis and virus-induced inflammation. Cell 2009, 137:1112-1123

61. Chan FK, Shisler J, Bixby JG, Felices M, Zheng L, Appel M, Orenstein J, Moss B, Lenardo MJ: a role for tumor necrosis factor receptor-2 and receptor-interacting protein in programmed necrosis and antiviral responses. J Biol Chem 2003, 278: 51613-51621

62. Daniels BP, Snyder AG, Olsen TM, Orozco S, Oguin TH, Tait SW, Martinez J, Gale M, Loo YM, Oberst A: RIPK3 restricts viral pathogenesis via cell death-independent neuroinflammation. Cell 2017, 169:301-313

63. Downey J, Pernet E, Coulombe F, Allard B, Meunier I, Jaworska J, Qureshi S, Vinh DC, Martin JG, Joubert P, Divangahi M: RIPK3 interacts with MAVS to regulate type I IFN- mediated immunity to Influenza A virus infection. PLoS Pathog 2017, 13:e1006326

64. Yenari MA, Kauppinen TM, Swanson RA: Microglial activation in stroke: therapeutic targets. Neurotherapeutics 2010, 7:378-391

65. Cherry JD, Olschowka JA, O'Banion MK: Neuroinflammation and M2 microglia: the good, the bad, and the inflamed. J Neuroinflammation 2014, 11:98

66. Amantea D, Nappi G, Bernardi G, Bagetta G, Corasaniti MT: Postischemic brain damage: pathophysiology and role of inflammatory mediators. FEBS J 2009, 276:13-26

67. Yang J, Zhao Y, Zhang L, Fan H, Qi C, Zhang K, Liu X, Fei L, Chen S, Wang M, Kuang F, Wang Y, Wu S: RIPK3/MLKL-mediated neuronal necroptosis modulates the M1/M2 polarization of microglia/macrophages in the ischemic cortex. Cereb Cortex 2018, 28:2622-2635

68. Lo EH, Dalkara T, Moskowitz MA: Neurological diseases: mechanisms, challenges and opportunities in stroke. Nat Rev Neurosci 2003, 4:399-415

69. Iannielli A, Bido S, Folladori L, Segnali A, Cancellieri C, Maresca A, Massimino L, Rubio A, Morabito G, Caporali L, Tagliavini F, Musumeci O, Gregato G, Bezard E, Carelli V, Tiranti V, Broccoli V: Pharmacological inhibition of necroptosis protects from dopaminergic neuronal cell death in Parkinson's disease models. Cell Rep 2018, 22: 2066-2079

70. Jiang T, Yu JT: Novel disease-modifying therapies for Alzheimer's disease. J Alzheimers Dis 2012, 31:475-492

71. Yang S, Lee DK, Shin J, Lee S, Baek S, Kim J, Jung H, Hah J, Kim Y: Nec-1 alleviates cognitive impairment with reduction of $\mathrm{A} \beta$ and tau abnormalities in APP/PS1 mice. EMBO Mol Med 2017, 9:61-77

72. Caccamo A, Branca C, Piras IS, Ferreira E, Huentelman MJ, Liang WS, Readhead B, Dudley JT, Spangenberg EE, Green KN, Belfiore R, Winslow W, Oddo S: Necroptosis activation in Alzheimer's disease. Nat Neurosci 2017, 20:1236-1246

73. Li J, McQuade T, Siemer AB, Napetschnig J, Moriwaki K, Hsiao YS, Damko E, Moquin D, Walz T, McDermott A, Chan FKM, Wu H: The RIP1/RIP3 necrosome forms a functional amyloid signaling complex required for programmed necrosis. Cell 2012, 27:1640-1649

74. Ito Y, Ofengeim D, Najafov A, Das S, Saberi S, Li Y, Hitomi J, Zhu H, Chen H, Mayo L, Geng J, Amin P, DeWitt JP, Mookhtiar AK, Florez M, Ouchida AT, Fan JB, Pasparakis M, Kelliher MA, Ravits J, Yuan J: RIPK1 mediates axonal degeneration by promoting inflammation and necroptosis in ALS. Science 2016, 353:603-608

75. Eisenberg D, Jucker M: The amyloid state of proteins in human diseases. Cell 2012, 148:1188-1203 
76. Cameron B, Landreth GE: Inflammation, microglia, and Alzheimer's disease. Neurobiol Dis 2010, 37:503-509

77. Lee CY, Landreth GE: The role of microglia in amyloid clearance from the AD brain. J Neural Transm 2010, 117:949-960

78. Cho MH, Cho K, Kang HJ, Jeon EY, Kim HS, Kwon HJ, Kim HM, Kim DH, Yoon SY: Autophagy in microglia degrades extracellular $\beta$ amyloid fibrils and regulates the NLRP3 inflammasome. Autophagy 2014, 10:1761-1775

79. Kalogeris T, Baines CP, Krenz M, Korthuis RJ: Cell biology of ischemia/reperfusion injury. Int Rev Cell Mol Biol 2012, 298:229-317

80. Dmitriev YV, Minasian SM, Demchenko EA, Galagudza MM: Study of cardioprotective effects of necroptosis inhibitors on isolated rat heart subjected to global ischemia-reperfusion. Bull Exp Biol Med 2013, 155:245-248

81. Solomon CG, Kent KC: Abdominal aortic aneurysms. N Engl J Med 2014, 371:2101-2108

82. Henderson EL, Geng YJ, Sukhova GK, Whittemore AD, Knox J, Libby P: Death of smooth muscle cells and expression of mediators of apoptosis by T lymphocytes in human abdominal aortic aneurysms. Circulation 1999, 99:96-104

83. López-Candales A, Holmes DR, Liao S, Scott MJ, Wickline Sa, Thompson RW: Decreased vascular smooth muscle cell density in medial degeneration of human abdominal aortic aneurysms. Am J Pathol 1997, 150:993-1007

84. Wang Q, Liu Z, Ren J, Morgan S, Assa C, Liu B: Receptor-interacting protein kinase 3 contributes to abdominal aortic aneurysms via smooth muscle cell necrosis and inflammation. Circ Res 2015, 116:600-611

85. Matthay MA, Zemans RL: The acute respiratory distress syndrome: pathogenesis and treatment. Annu Rev Pathol 2011, 6:147-163

86. Soriano JB, Abajobir AA, Abate KH, Abera SF, Agrawal A, Ahmed MB, et al: Global, regional, and national deaths, prevalence, disability-adjusted life years, and years lived with disability for chronic obstructive pulmonary disease and asthma, 1990-2015: a systematic analysis for the Global Burden of Disease Study 2015. Lancet Respir Med 2017, 5:691-706

87. Kasahara Y, Tuder RM, Cool CD, Lynch DA, Flores SC, Voelkel NF: Endothelial cell death and decreased expression of vascular endothelial growth factor and vascular endothelial growth factor receptor 2 in emphysema. Am J Respir Crit Care Med 2001, 163:737-744

88. Imai K, Mercer BA, Schulman LL, Sonett JR, D'Armiento JM: Correlation of lung surface area to apoptosis and proliferation in human emphysema. Eur Respir J 2005, 25:250-258

89. Patton H, Misel M, Gish RG: Acute liver failure in adults: an evidence-based management protocol for clinicians. Gastroenterol Hepatol 2012, 8:161-212

90. Heidelbaugh JJ, Bruderly M: Cirrhosis and chronic liver failure: part I. Diagnosis and evaluation. Am Fam Physician 2006, 74:756-762

91. Krenkel O, Mossanen JC, Tacke F: Immune mechanisms in acetaminophen-induced acute liver failure. Hepatobiliary Surg Nutr 2014, 3:331-343

92. Schneider AT, Gautheron J, Tacke F, Vucur M, Luedde T: Receptor interacting protein kinase 1 (RIPK1) in hepatocytes does not mediate murine acetaminophen toxicity. Hepatology 2016, 64:306-308

93. Fuster D, Samet JH: Alcohol use in patients with chronic liver disease. N Engl J Med 2018, 379:1251-1261

94. Wang S, Ni HM, Dorko K, Kumer SC, Schmitt TM, Nawabi A, Komatsu M, Huang H, Ding WX: Increased hepatic receptor interacting protein kinase 3 expression due to impaired proteasomal functions contributes to alcohol-induced steatosis and liver injury. Oncotarget 2016, 7:17681-17698

95. Whitcomb DC: Acute pancreatitis. N Engl J Med 2006, 354: $2142-2150$

96. Xavier RJ, Podolsky DK: Unravelling the pathogenesis of inflammatory bowel disease. Nature 2007, 448:427-434
97. Pierdomenico M, Negroni A, Stronati L, Vitali R, Prete E, Bertin J, Gough PJ, Aloi M, Cucchiara S: Necroptosis is active in children with inflammatory bowel disease and contributes to heighten intestinal inflammation. Am J Gastroenterol 2014, 109:279-287

98. Negroni A, Colantoni E, Pierdomenico M, Palone F, Costanzo M, Oliva S, Tiberti A, Cucchiara S, Stronati L: RIP3 AND pMLKL promote necroptosis-induced inflammation and alter membrane permeability in intestinal epithelial cells. Dig Liver Dis 2017, 49:1201-1210

99. Alinia H, Moradi Tuchayi S, Smith JA, Richardson IM, Bahrami N, Jaros SC, Sandoval LF, Farhangian ME, Anderson KL, Huang KE, Feldman SR: Long-term adherence to topical psoriasis treatment can be abysmal: a 1-year randomized intervention study using objective electronic adherence monitoring. Br J Dermatol 2017, 176:759-764

100. Gisondi P, Del Giglio M, Girolomoni G: Treatment approaches to moderate to severe psoriasis. Int J Mol Sci 2017, 18:e2427

101. Armstrong AW, Robertson AD, Wu J, Schupp C, Lebwohl MG: Undertreatment, treatment trends, and treatment dissatisfaction among patients with psoriasis and psoriatic arthritis in the United States: findings from the National Psoriasis Foundation Surveys, 2003-2011. JAMA Dermatol 2013, 149:1180-1185

102. Lande R, Gregorio J, Facchinetti V, Chatterjee B, Wang YH, Homey B, Cao W, Wang YH, Su B, Nestle FO, Zal T, Mellman I, Schröder JM, Liu YJ, Gilliet M: Plasmacytoid dendritic cells sense selfDNA coupled with antimicrobial peptide. Nature 2007, 449:564-569

103. Kryczek I, Bruce AT, Gudjonsson JE, Johnston A, Aphale A, Vatan L, Szeliga W, Wang Y, Liu Y, Welling TH, Elder JT, Zou W: Induction of IL-17+ T cell trafficking and development by IFN- $\gamma$ : mechanism and pathological relevance in psoriasis. J Immunol 2008, 181:4733-4741

104. Nograles KE, Davidovici B, Krueger JG: New insights in the immunologic basis of psoriasis. Semin Cutan Med Surg 2010, 29:3-9

105. Saito N, Honma M, Shibuya T, Inuma S, Igawa S, Kishibe M, Ishida-Yamamoto A: RIPK1 downregulation in keratinocyte enhances TRAIL signaling in psoriasis. J Dermatol Sci 2018, 91:79-86

106. Guo Q, Wang Y, Xu D, Nossent J, Pavlos NJ, Xu J: Rheumatoid arthritis: pathological mechanisms and modern pharmacologic therapies. Bone Res 2018, 6:15

107. Rutherford A, Nikiphorou E, Galloway J: Rheumatoid arthritis. Edited by Miedany YE. In Comorbidity in Rheumatic Diseases. Cham, Switzerland: Springer, 2017. pp. 53-79

108. Conos SA, Chen KW, De Nardo D, Hara H, Whitehead L, Núñez G, Masters SL, Murphy JM, Schroder K, Vaux DL, Lawlor KE, Lindqvist LM, Vince JE: Active MLKL triggers the NLRP3 inflammasome in a cell-intrinsic manner. Proc Natl Acad Sci 2017, 114:e961-e969

109. Vince JE, Wong WW, Gentle I, Lawlor KE, Allam R, O'Reilly L, Mason K, Gross O, Ma S, Guarda G, Anderton H, Castillo R, Häcker G, Silke J, Tschopp J: Inhibitor of apoptosis proteins limit RIP3 kinasedependent interleukin-1 activation. Immunity 2012, 36:215-227

110. Matthys P, Vermeire K, Heremans H, Billiau A: The protective effect of IFN- $\gamma$ in experimental autoimmune diseases: a central role of mycobacterial adjuvant-induced myelopoiesis. J Leukoc Biol 2000, 68:447-454

111. Makris K, Spanou L: Acute kidney injury: definition, pathophysiology and clinical phenotypes. Clin Biochem Rev 2016, 37:85-98

112. Schreiber A, Rousselle A, Becker JU, von Mässenhausen A, Linkermann A, Kettritz R: Necroptosis controls NET generation and mediates complement activation, endothelial damage, and autoimmune vasculitis. Proc Natl Acad Sci 2017, 114:e9618-e9625

113. Kers J, Leemans JC, Linkermann A: An overview of pathways of regulated necrosis in acute kidney injury. Semin Nephrol 2016, 36:139-152

114. Mulay SR, Linkermann A, Anders H-J: Necroinflammation in kidney disease. J Am Soc Nephrol 2016, 27:27-39

115. Klipa D, Mahmud N, Ahsan N: Antibody immunosuppressive therapy in solid organ transplant: part II. MAbs 2010, 2:607-612

116. Mocarski ES, Guo H, Kaiser WJ: Necroptosis: the Trojan horse in cell autonomous antiviral host defense. Virology 2015, 480:160-166 